\title{
MANAJEMEN HUBUNGAN MASYARAKAT DALAM \\ MENGEMBANGKAN LEMBAGA PENDIDIKAN \\ (Studi Kasus di SMK Negeri 1 Dlanggu Mojokerto)
}

\author{
Muhammad Nur Hakim \\ Institut Pesantren KH Abdul Chalim \\ (munuhakim92@gmail.com)
}

\begin{abstract}
Abstrak
Sekolah dan masyarakat adalah satu kesatuan yang tidak dapat dipisahkan, sebab keduanya saling memberi dan menerima. Sekolah sebagai lembaga pendidikan dan lembaga sosial masyarakat yang diberikan tanggung jawab dalam menentukan nasib generasi bangsa mereka ke depan, sedangkan masyarakat selain sebagai konsumen, juga memiliki peran dan tanggung jawab sukses atau tidaknya penyelenggaraan pendidikan. Masyarakat secara luas yang termasuk di antaranya, orang tua peserta didik, pemerintah, instansi/lembaga perusahaan dan sebagainya. Harapan utama dari kinerja humas adalah untuk menarik masyarakat agar peduli dan mempercayai serta menggunakan lulusan atau layanan yang ditawarkan oleh lembaga pendidikan. Sebagaimana yang terjadi sekarang, banyak lembaga terutama lembaga pendidikan yang mengalami krisis kepercayaan dari masyarakat dalam menjalankan rutinitas program-program lembaga pendidikan. Melihat hal ini, peran humas menjadi sangat penting dalam suatu internal kelembagaan organisasi atau lembaga pendidikan. Sebab humas adalah praktisi yang memang berfungsi sebagai perantara untuk menjembatani antara lembaga yang diwakili dengan lembaga yang ada di dalam masyarakat (atau masyarakat itu sendiri), akibatnya humas bertanggung jawab secara merata terhadap lembaga yang diwakilinya dengan masyarakat yang terkait.

Kata Kunci: humas, lembaga pendidikan
\end{abstract}

\begin{abstract}
Schools and communities is a unity that can not be separated, as both mutual give and take. The school as a social institution and the institution of the community is given the responsibility of determining the fate of their nation to the next generation, while the society other than as
\end{abstract}

Nidhomul Haq: Jurnal Manajemen Pendidikan Islam

ISSN: 2503-1481 Hal: 121-139

DOI: $10.31538 /$ ndh.v4i1.245 
consumers, also have roles and responsibilities the successful or not Organization of education. The community widely including learners, parents, Government, company/institution agency and so on. The main expectations of the performance of public relations is to attract people to care and trust as well as graduates or using the services offered by the institution. As is happening now, many agencies especially the institution suffered a crisis of confidence of the public in carrying out routine institution programs. See this, the role of public relations became very important in an internal institutional organisation or institution. Because of public relations practitioners are indeed function as an intermediary to bridge between the institutions represented by agencies that exist within the Community (or the community itself), as a result of public relations responsibility evenly against the institution It represents the associated with the community.

Key words: public relations, educational institutions

\section{PENDAHULUAN}

Sejatinya pendidikan di dunia ini merupakan proses untuk merubah jiwa anak dengan cara mengarahkan dan membimbing potensi yang dimilikinya secara optimal. Tugas pendidikan juga mempersiapkan peserta didik agar mudah berinteraksi dengan lingkungan sekitarnya, seperti keluarga, sekolah, masyarakat, bahkan bangsa, dan Negara tempat mereka hidup dan melakukan semua aktivitasnya. ${ }^{1}$

Di zaman ini, kemajuan lembaga pendidikan justru ditentukan oleh masyarakat. Karena, kemajuan lembaga pendidikan dapat dilihat dari seberapa jauh masyarakat dapat mempercayai mereka untuk mengemban tugasnya. Sehingga, lembaga pendidikan atau para pemimpin pendidikan khususnya harus membuat strategi yang mampu menciptakan iklim lembaga yang dinamis dan responsif terhadap kebutuhan masyarakat di sekitarnya.

Jika dikaji terus menerus, maka setiap lembaga pendidikan diharuskan mampu mensinergikan dan mengikutsertakan masyarakat dalam mengelola dan mengembangkan proses manajerial di lembaganya. Pernyataan ini disebut sebagai pendidikan bersama masyarakat, yaitu lembaga berusaha mengikutsertakan masyarakat di setiap program pemerintah. Hal ini disebabkan karena kebutuhan nyata yang dihadapi masyarakat merupakan tujuan utama lemabaga pendidikan itu berdiri. ${ }^{2}$

Namun, melihat realita saat ini

1 E Syarifudin, Manajemen Pendidikan (Jakarta: Diadit Media, 2011), 33. 
yang mana sering terjadi hubungan yang kurang harmonis antara lembaga pendidikan terhadap masyarakat maupun sebaliknya. Hal ini jelas disebabkan oleh banyak factor, dan idealnya lembaga pendidikan dan masyarakat harus terjalin hubungan yang harmonis. Jika organisasi tidak menjalin hubungan yang baik dengan masyarakat, maka ada rasa enggan untuk memberikan aspirasi dari masyarakat kepada lembaga tersebut. Sehingga timbul kesenjangan hubungan antara sekolah dengan masyarakat sebagai pelanggan pendidikan. Akibatnya, komunikasi di dalam lembaga tidak berjalan dengan baik. ${ }^{3}$

Minimnya sinergitas antara lembaga dan masyarakat internal maupun eksternal adalah kurang maksimalnya peran humas dalam sebuah organisasi. Faktor lain adalah tidak ditempatkannya fungsi humas di dalam lembaga pendidikan secara benar. ${ }^{4}$ Kesenjangan tersebut berdampak pada citra atau persepsi masyarakat terhadap image

${ }^{2}$ F. Winarni, "Reorientasi Pendidikan Nilai Dalam Menyiapkan Kepemimpinan Masa Depan," Cakrawala Pendidikan XXV, no. 1 (2006): 149.

3 Akmal Mundiri, "Strategi Lembaga Pendidikan Islam Dalam Membangun Branding Image," Pedagogik 3, no. 2 (2016): 61-62.

${ }^{4}$ Feliza Zubair, Retasari Dewi, and Ade Kadarisman, "Strategi Komunikasi Publik Dalam Membangun Pemahaman Mahasiswa Terhadap Penerapan Ptnbh," Profetik Jurnal Komunikasi 11, no. 2 (2018): 76. lembaga pendidikan yang kurang baik. Karena dengan humas yang berada di posisi yang baik dalam lembaga pendidikan dapat mengarahkan persepsi dan opini baik dari masyarakat terkait dengan pendidikan yang dijalankan oleh sebuah sekolah atau lembaga pendidikan.

Selain itu, terkadang yang menyebabkan bidang humas kurang berjalan baik dalam organisasi sekolah adalah karena manajemen yang kurang baik, akibatnya berpengaruh terhadap image sekolah. Ada beberapa hal yang menyebabkan partisipasi masyarakat Indonesia terhadap pendidikan masih rendah antara lain: (1) kondisi sosial, kultural, geografis masyarakat Indonesia, (2) ketidakberdayaan financial masyarakat dalam hal pembiayaan, dan (3) pembuatan kebijakan yang kurang memperhatikan kondisi lapangan. ${ }^{5}$

Hubungan partisipasi masyarakat dengan lembaga pendidikan sebagai bentuk kontribusi terhadap kemajuan lembaga pendidikan Islam perlu kiranya hal ini mendapat perhatian secara manajerial. Sebab masyarakat harus menyadari bahwa mereka memiliki

\footnotetext{
${ }^{5}$ Sitti Roskina Mas, "Partipasi Masyarakat Dan Orang Tua Dalam Penyelengaraan Pendidikan," Jurnal el-Hikmah VIII, no. 2 (2011): 185, http://ejournal.uin-
} 
peranan yang sangat penting, karena kepercayaan masyarakat terhadap lembaga pendidikan Islam menjadi salah satu kunci kemajuan lembaga tersebut.

Belum lagi apabila hubungan antara pihak sekolah dan wali murid serta masyarakat terjalin dengan baik tentu nantinya dapat memberikan kotribusi yang lebih baik dan signifikan terhadap pengembangan pendidikan maupun pembelajaran sehingga dapat bersama mewujudkan pendidikan di sekolah yang bermutu. $^{6}$

Peran humas dalam lembaga pendidikan merupakan salah satu komponen inti dan penting dalam manajemen pendidikan. Yang mana, proses manajemen humas bagi pendidikan adalah proses perencanaan, pelaksanaan, pengendalian, dan evaluasi terhadap program-program yang berpusat terhadap interaksi sosial lembaga dengan memberdayakan potensi sumber daya dengan maksimal. Tahapan-tahapan manajemen tersebut tidak dapat bergerak secara mandiri tanpa mengikutsertakan fungsi-fungsi lainnya. Karena, setiap melaksanakan fungsi manajerial tertentu maka fungsi manajerial yang lainnya akan mengikuti sebagai tahap selanjutnya.

\section{PEMBAHASAN}

\section{Manajemen Hubungan Masyarakat}

Secara umum, pemahaman manajemen merupakan proses yang sistematis yang terdiri dari pelaksanan fungsi-fungsi dari perencanaan, pengorganisasian, penggerakan dan pengawasan untuk mencapai tujuan yang telah ditetapkan melalui pendayagunaan sumber daya yang dimiliki baik itu berupa manusia maupun sumber daya non manusia lainnya. ${ }^{7}$

Istilah manajemen jika dikaji lebih dalam itu mengacu pada proses pelaksanaan aktivitas yang diselesaikan secara efisien dengan melalui pendayagunaan orang lain agar mencapai tujuan secara efektif. Sebuah gambaran yang sederhana namun cukup menjadi sebuah strategi untuk pemberdayaan seluruh potensi yang ada dalam suatu lembaga yang pasti diarahkan untuk pencapaian tujuan-tujuan dari lembaga tersebut.

Membahas terkait humas pasti ingatan kita akan tertuju pada hal yang berhubungan dengan komunikasi, konfrensi pers, informasi, public relation, dan semacamnya. Secara garis besar agar dapat menyeimbangkan dan menyamakan visi lembaga pendidikan dengan masyarakat perlu adanya pengelolaan hubungan antara lembaga dan

\footnotetext{
7 Samsuni Samsuni, "Manajemen Sumber Daya Manusia," Al-Falab: Jurnal Ilmiah Keislaman dan Kemasyarakatan 17, no. 1 (March 1, 2017): 105,

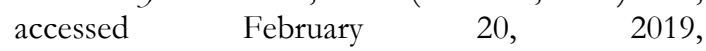


masyarakatnya. ${ }^{8}$ Agar tercipta suatu hubungan yang harmonis seperti adanya kritik, saran dan tanggapan yang baik dari masyarakat, terlebih bisa ikut berkontribusi dalam mewujudkan lembaga pendidikan yang bermutu.

Hubungan masyarakat dalam dunia Pendidikan adalah salah satu bagian dari komponen kegiatan manajerial lembaga pendidikan, yang berkaitan dengan terwujudnya kerjasama yang harmonis antara pihak dari lembaga pendidikan dengan masyarakat sebagai salah satu yang menjadi pengguna dari lulusannya. ${ }^{9}$ Karena salah satu tugas humas terhadap masyarakat adalah membuat sebuah kepercayaan kepada lembaga pendidikan, yang tentu saja akan berdampak positif seperti menambah perhatian dan kepedulian masyarakat terkait peningkatan kualitas pendidikan, yang pada akhirnya dapat menunjang proses kegiatan belajar mengajar di lembaga pendidikan yang bersangkutan.

Pengertian humas secara umum adalah rangkaian yang khas antara sebuah organisasi dengan publiknya, atau dalam

http://ejurnal.staialfalahbjb.ac.id/index.php/alfala hjikk/article/view/19.

${ }^{8}$ Zubair, Dewi, and Kadarisman, "Strategi Komunikasi Publik Dalam Membangun Pemahaman Mahasiswa Terhadap Penerapan Ptnbh," 78. hal ini yaitu antara lembaga pendidikan dengan para warga yang berada di dalamnya (pendidik, peserta didik, dan tenaga kependidikan) beserta para warga dari luar lembaga (wali murid, masyarakat, institusi luar, komite sekolah, dll) untuk menunjang pendidikan agar lebih bermutu dan berkualitas. ${ }^{10}$

Hampir semua aspek yang berkaitan dengan lembaga pendidikan memerlukan sebuah manajemen, karena dengan manajemen tujuan yang telah ditentukan dapat dicapai dengan lebih efektif dan efisien. ${ }^{11}$ Sebab adanya manajemen ini diperuntukkan untuk mengelola sumber daya yang dimiliki dengan baik dan benar. Sama halnya humas yang tidak akan bisa melaksanakan peran dan tugasnya dengan baik dan benar jika tanpa ada manajemen yang baik pula dari pihak lembaganya.

Adapun pengertian manajemen humas adalah suatu proses dalam menangani perencanaan, pengorganisasian, mengkomunikasikan serta pengkoordinasian yang secara serius dan rasional dalam upaya pencapaian

9 Mundiri, "Strategi Lembaga Pendidikan Islam Dalam Membangun Branding Image,” 62.

10 Ira Nur Harini and Karwanto, "Manajemen Hubungan Masyarakat Dalam Upaya Peningkatan Pencitraan Sekolah," Jurnal Inspirasi Manajemen Pendidikan 4, no. 4 (2014): 9.

${ }^{11}$ Ibid., 11. 
tujuan bersama dari lembaga pendidikan yang diwakilinya. Dan untuk merealisasikan itu semua banyak hal yang harus dilakukan oleh humas dalam suatu lembaga pendidikan.

Dengan adanya manajemen humas, tentu kinerjanya dapat membantu lembaga pendidikan baik dari dalam lembaga maupun dari luar lembaganya. Akan tetapi, humas dalam sebuah lembaga tidak hanya bertugas untuk publisitas belaka, namun lebih bersifat agar bagaimana pihak lembaga dapat membangun hubungan kerja sama dengan pihak-pihak dari luar lembaga yang berupa networking. ${ }^{12}$ Yang mana hubungan kerja sama ini sangatlah urgen untuk dilaksanakan terutama dengan kondisi zaman sekarang yang serba modern, dan tetap bertujuan agar memudahkan dalam meningkatkan kualitas penyelenggaraan pendidikan di sebuah lembaga pendidikan.

Berdasarkan penjelasan di atas, sudah jelas dalam konteks pendidikan ini humas atau public relation (PR) adalah termasuk salah satu elemen yang penting dalam suatu lembaga pendidikan yang berkembang maupun yang sudah maju. Sebab untuk menarik kepedulian dan partisipasi masyarakat tidaklah mudah, karena persepsi setiap masyarakat

\footnotetext{
${ }^{12}$ Muhammad Nur Hakim, "Implementasi Manajemen Berbasis Sekolah Dalam Mewujudkan Sekolah Islam Unggulan," Nidhomul Haq: Jurnal Manajemen Pendidikan Islam 1, no. 2 (2016): 110, accessed November 3, 2018, http://ejournal.ikhac.ac.id/index.php/nidhomulhaq/article /view/7.
}

terhadap lembaga pendidikan itu berbeda, sehingga dengan adanya manajemen humas diharapkan semua kalangan masyarakat ikut peduli dan berpartisipasi bahkan berkontribusi dalam upaya meningkatkan kualitas pendidikan.

\section{Konsep Humas dalam}

\section{Mengembangkan Lembaga}

\section{Pendidikan}

Public relations atau yang lebih kita kenal sebagai humas memiliki peran dalam sebuah lembaga terutama pendidikan, karena berhubungan dengan fungsi-fungsi manajemen maupun tujuan utama yang ada pada lembaga pendidikan. Fungsi yang paling mendasar tersebut merupakan proses untuk mencapai tujuan pokok dari sebuah lembaga yang pada umumnya berkaitan dengan pemanfaatan berbagai macam sumber daya yang dimiliki dan yang ada di lembaga tersebut. ${ }^{13}$

Apabila kita meninjau dari teori manajemen sumber daya yang dimiliki oleh lembaga yakni meliputi sumber daya manusia, sumber daya material, sumber daya sarana dan prasarana, sumber pembiayaan untuk mencukupi biaya operasional, dan strategi dan metode yang digunakan untuk menggerakan kelembagaan tersebut, serta lembaga pendidikan diharapkan dapat

13 Pardjono Yogi Irfan Rosyadi, "Peran Kepala Sekolah Sebagai Manajer Dalam Meningkatkan Mutu Pendidikan Di SMP 1 Cilawu Garut," Jurnal Akuntabilitas Manajemen Pendidikan 3, no. 1 (2015): 128. 
mewujudkan kerjasama dengan pihak luar agar mudah mendapatkan kepercayaan, perhatian, dan kepedulian masyarakat sehingga memudahkan dalam mengembangkan pendidikan yang berkualitas.

Dan keberhasilan dari peran humas dalam menunjang manajemen di lembaga pendidikan dalam mencapai target tujuan yang telah direncanakan bersama tergantung kepada kemampuan dalam memanfaatkan sumber daya yang dimiliki oleh lembaga pendidikan serta dapat menarik sikap peduli untuk ikut berkontribusi dalam mengembangkan lembaga pendidikan tersebut. ${ }^{14}$ Karena sebuah lembaga pendidikan takkan mampu menjadi lembaga yang berkualitas dan unggul tanpa ada campur tangan dari pihak lain di luar lembaga.

Kemudian humas sebagai media penghubung antara pimpinan lembaga dengan publiknya, baik dalam upaya membina hubungan masyarakat internal ataupun eksternal. Kegiatan utama dari humas dalam mewakili pimpinan manajemen suatu lembaga pendidikan, merupakan bentuk aktifitas komunikasi dua arah yang menjadi ciri-ciri dari peran

14 Hakim, "Implementasi Manajemen Berbasis Sekolah Dalam Mewujudkan Sekolah Islam Unggulan," 106. dan tugas humas. Karena sebagian dari peran dan tugas humas adalah bertindak sebagai sumber informasi (source of informations) dan merupakan saluran informasi (channel of informations) antara pihak lembaga dan publiknya. ${ }^{15}$

Perkembangan humas yang berhubungan dengan perannya, baik secara praktis maupun profesional dalam lembaga pendidikan sebagai salah satu kunci dalam memahami fungsi humas dan komunikasi lembaga terhadap publiknya. Peran public relations/humas dalam suatu lembaga dapat terbagi dalam empat kategori, yaitu:

a. Penasihat ahli (expert prescriber). ${ }^{16}$ Seorang pakar humas yang berpengalaman dan memiliki kemampuan tinggi dapat membantu mencarikan solusi dalam penyelesaian masalah hubungan dengan publiknya. Hubungan praktisi pakar humas dengan manajemen lembaganya bagaikan hubungan antara pendidik dan peserta didiknya, dalam arti pihak manajemen

15 Nurul Yaqien, "Membangun Kepercayaan Masyarakat Pada Madrasah Melalui Pameran Pendidikan," Madrasab 2, no. 2 (2010): 205.

16 Amrullah Hasbana, "Perpustakaan Sebagai Lembaga Komunikasi Organisasi Kampus," Al-Maktabab 13, no. 1 (2014): 54. 
bersikap pasif untuk menerima atau bahkan mempercayai apa yang telah disarankan oleh pakar humas tersebut dalam upaya memecahkan dan mengatasi persoalan public relations yang tengah dihadapi oleh lembaga pendidikan yang bersangkutan.

b. Fasilitator komunikasi (communication fasilitator). ${ }^{17}$ Praktisi humas bertindak sebagai komunikator atau mediator dalam upaya membantu pihak manajemen lembaga dalam hal mendengar apa yang diperlukan oleh publiknya. Dipihak lain, dia juga dituntut mampu menjelaskan kembali keinginan, kebijakan dan harapan organisasi kepada pihak publiknya. Sehingga dengan komunikasi timbal balik tersebut dapat tercipta saling pengertian, mempercayai, menghargai, mendukung dan toleransi yang baik dari kedua belah pihak.

c. Fasilitator proses pemecahan masalah (problem solving process fasilitator). ${ }^{18}$ Peran praktisi humas dalam proses menyelesaikan permasalahan dalam bidang

17 Rofiq Anwar, "Peran Praktisi Public Relations Dalam Organisasi-Organisasi Di Yogyakarta," An-Nida 7, no. 1 (2015): 52.

18 Enjang Pera Irawan, "Penerapan Peran Public Relations Pada Program Employee Relations Sebagai Upaya Meningkatkan Loyalitas Karyawan," LONTAR: Jurnal Ilmu Komunikasi, no. 2 (2018): 19, accessed February 25, 2019, http:/ /ejurnal.lppmunsera.org/index.php/LONTAR/articl e/view/538. humas ini merupakan bagian dari tim manajemen. Hal ini dimaksudkan untuk membantu pimpinan lembaga pendidikan baik sebagai penasihat (adviser) hingga mengambil keputusan dalam mengatasi persoalan atau krisis yang tengah dihadapi secara rasional dan profesional.

d. Teknisi komunikasi (communication technician). ${ }^{19}$ Peran teknisi komunikasi menjadikan praktisi humas sebagai wartawan yang nantinya menyediakan layanan komunikasi secara teknis. Sistem komunikasi dalam sebuah lembaga tergantung dari masing-masing bagian, yaitu secara teknis komunikasi, baik media atau arus komunikasi yang digunakan dari tingkat pimpinan dan bawahan tentu berbeda dari tingkat bawahan ke tingkat atasan.

Dalam sebuah lembaga pendidikan bahkan hampir semua lembaga membutuhkan adanya humas sebagai salah satu alat untuk mengembangkan diri karena peran dan tugas dari humas tak dapat dipungkiri sangatlah penting. Sehingga perlu pengemasan yang efektif dalam pelaksanaannya agar mendapat hasil dengan lebih efisien. Agar hal ini dapat dicapai dengan baik, tentu perlu

19 Hasbana, "Perpustakaan Sebagai Lembaga Komunikasi Organisasi Kampus,” 52. 
dilaksanakan dengan cara mempersiapkan program kerja humas dengan tepat agar mudah dalam aplikasinya. ${ }^{20}$

Posisi humas dengan manajemen tak terpisahkan, dan harus selalu berdekatan. Hal ini sesuai dengan fungsi manajemen di dalam sebuah lembaga/organisasi. Dengan peran dan tugas humas maka ia perlu diletakkan sejajar dengan para staf manajemen puncak. Dengan begitu, humas dapat mengorganisasi seluruh kegiatan komunikasi baik secara internal maupun eksternal. Sebab humas merupakan salah satu pendukung dalam mengatur dan mengelola lembaga.

Dalam konteks pendidikan, humas dalam implementasinya merupakan sebuah profesi untuk melayani publiknya, serta ikut menentukan tujuan lembaga dengan membuat program kerja, strategi, pelaksanaan program kerja, dan menilai hasil kerjanya. Humas berusaha menempatkan manajer sebagai top manajemen dalam kepemimpinannya, dan mewujudkan tujuan lembaga pendidikan dengan cara seefektif dan seefisien mungkin agar dapat menjadi kenyataan demi kontinuitas lembaga pendidikan

20 Hakim, "Implementasi Manajemen Berbasis Sekolah Dalam Mewujudkan Sekolah Islam Unggulan," 105. tersebut.

Dalam upaya pengembangan dan peningkatan mutu lembaga pendidikan, humas memiliki fungsi-fungsi yang cukup relevan dalam menghadapi perubahan zaman, antara lain:

a. Mampu sebagai motivator dalam menyampaikan komunikasi secara langsung (komunikasi tatap muka) dan tidak langsung (melalui media pers) kepada pimpinan lembaga dan publik intern (dosen/guru, karyawan, dan mahasiswa/siswa).

b. Mendukung dan menunjang kegiatan-kegitan yang berkaitan dengan mempublikasi lembaga pendidikan. Dalam hal ini humas bertindak sebagai pengelola informasi kepada publik intern dan publik ekstern, seperti: menyampaikan informasi kepada pers dan promosi.

c. Menciptakan suatu citra yang positif terhadap lembaga pendidikannya. ${ }^{21}$

Sedangan untuk dapat menunjang keberhasilan dalam mencapai tujuan utama lembaga pendidikan, dibutuhkan

${ }^{21}$ Zulkarnain Nasution, Manajemen Humas Di Lembaga Pendidikan: Konsep, Fenomena, Dan Aplikasinya (Malang: UMM Press, 2010), 23. 
kerjasama dari berbagai pihak lain baik di dalam lembaga maupun di luar lembaga tersebut. ${ }^{22}$ Dengan demikian pihak humas dalam lembaga pendidikan harus berfungsi sedemikian rupa agar dapat meningkatkan mutu serta relevansi dan efisiensi sebuah lembaga pendidikan agar siap dan mudah dalam mengahadapi tantangan dan tuntutan perubahan kehidupan. $^{23}$ Sehingga diperlukan pembaharuan pendidikan dibidang hubungan lembaga dengan masyarakatnya agar lebih terencana dan terarah, serta berkesinambungan dalam upaya mewujudkannya.

\section{HASIL DAN PEMBAHASAN}

\section{Manajemen Humas}

dalam

Mengembangkan

Lembaga

\section{Pendidikan}

Pemimpin sebagai manajer atau sebaliknya, dalam sebuah lembaga pendidikan memiliki fungsi penting yaitu memberi kemudahan dalam proses mencapai tujuan secara komparatif di antara para anggota dan pada saat yang sama menyediakan kesempatan bagi pertumbuhan serta perkembangan pribadi mereka. Menurut Assumpta kepemimpinan adalah suatu konsep manajemen dalam kehidupan berorganisasi, mempunyai kedudukan yang strategis dan merupakan suatu gejala

22 Hakim, "Implementasi Manajemen Berbasis Sekolah Dalam Mewujudkan Sekolah Islam Unggulan," 105. sosial yang selalu dibutuhkan dalam kehidupan berkelompok. ${ }^{24}$

Melihat hasil penelitian di SMKN 1 Dlanggu menunjukkan bahwa kepemimpinan dalam sebuah lembaga juga merupakan sentral dari semua kegiatan. Seorang kepala sekolah sebagai pemimpin merupakan pengelola dan pengendali utama dalam mencapai suatu tujuan yang telah ditargetkan, bahkan dalam mengembangkan lembaga pendidikan seorang pemimpin menjadi faktor penentu keberhasilan dari pengembangan lembaga tersebut.

Di sekolah ini kepala sekolah juga memberikan ruang gerak yang bebas namun tetap dalam prosedur yang telah ditentukan dalam mengembangkan pribadi dari setiap pihak yang memiliki tanggung jawab dan kepentingan dalam mengurus dan mengelola hubungan lembaga dengan masyarakatnya.

Persoalan ini sesuai dengan temuan lain yang mengemukakan bahwa pihak humas memang seharusnya memiliki kemampuan untuk dapat menjalin komunikasi dan kerjasama yang baik dan harmonis dengan masyarakat, agar tercipta pandangan yang positif dari masyarakat terhadap kondisi lembaga maupun pendidikannya. ${ }^{25}$

Dengan demikian baik kepala

23 Harini and Karwanto, "Manajemen Hubungan Masyarakat Dalam Upaya Peningkatan Pencitraan Sekolah," 9.

${ }^{24}$ Nasution, Manajemen Humas Di Lembaga Pendidikan: Konsep, Fenomena, Dan Aplikasinya, 52. 
sekolah maupun waka humas di lembaga pendidikan tidak terlepas dari prinsipprinsip komunikasi yang efektif dalam hubungannya dengan masyarakat agar mudah dalam menyelesaikan persoalan yang dihadapi bersama, diantaranya: ${ }^{26}$

a. Prinsip human relations dalam komunikasi dengan sesama manusia.

Manusia memang tidak dapat terlepas dari interaksi dengan sesama melalui kegiatan berkomunikasi. Oleh sebab itu, prinsip hubungan sesama manusia terutama di SMKN 1 Dlanggu ini memberikan peran penting, hal ini ditunjukkan dengan seringnya kepala sekolah beserta tenaga kependidikannya melakukan raat koordinasi untuk mengembangkan lembaga melalui semua komponen yang dimiliki termasuk humas.

b. Prinsip komunikasi interpersonal.

Komunikasi ini yang diciptakan bersifat dua arah

25 Harini and Karwanto, "Manajemen Hubungan Masyarakat Dalam Upaya Peningkatan Pencitraan Sekolah," 14.

${ }^{26}$ Nasution, Manajemen Humas Di Lembaga Pendidikan: Konsep, Fenomena, Dan Aplikasinya, 54. dan dialogis. Komunikasi tersebut merupakan salah satu prinsip humas dalam membentuk pribadi manusia sebagai pihak yang mewakili lembaganya dengan masyarakat sebagai pemakai. Pihak humas SMKN 1 Dlanggu juga selalu melakukan komunikasi baik secara langsung maupun tidak langsung karena mereka sadar bahwa mereka membutuhkan komunikasi yang baik untuk menyelesaikan semua masalah pendidikan yang berkaitan dengan peserta didik, keluarga dan sekolah.

c. Prinsip gaya partisipatif dilakukan untuk menggali aspirasi.

Hasil temuan di SMKN 1 Dlanggu menunjukkan bahwa dari semua pihak baik pendidik, tenaga pendidikan, peserta didik, wali murid, dan masyarakat memberikan masukan saran dan aspirasi mereka sehingga kebijakan sekolah dapat dijalankan dengan lancar dan efektif. Khususnya dalam memilih 
dan menentukan kebijakan yang dibutuhkan.

d. Prinsip persuasif.

Seorang pemimpin harus memiliki kemampuan pempengaruhi orang lain. Untuk mempersuasif orang lain pemimpin harus bisa dipercayai, karena kejujuran, objektivitas, lebih memikirkan pihak lain, lebih memberi dan memperhatikan pelayanan, menunjukan profesionalitas, luas pandangan dan supel, sehingga menyebabkan pemimpin tersebut berpengaruh terhadap bawahan maupun teman kerja.

e. Prinsip informatif.

Pihak humas sebagai pengelola utama humas di SMKN 1 Dlanggu, diharuskan mempunyai kemampuan mengelola dan menyampaikan informasi yang strategis kepada publik yang ada di lembaga tersebut maupun publik yang berada diluar lembaga / publik eksternal. Hal ini dibuktikan dengan seringnya wali murid, masyarakat, bahkan instansi lain yang datang ke SMKN 1 Dlanggu.

f. Prinsip membina hubungan.

Dalam hal ini pemimpin harus memiliki kreatifitas dan inovasi dalam membina hubungan masyaraka. Baik kepala sekolah maupun waka humas SMKN 1 Dlanggu berupaya untuk terus membina hubungan yang baik dengan pendidik, tenaga kependidikan, dan peserta didik dalam memberikan dorongan dan motivasi. Sedangkan kepada orang tua dan institusi luar dengan cara membina kerjasama yang saling memberikan keuntungan, seperti menggalang beasiswa, bantuan bangunan, dan pemberian sarana, fasilitas, dan alat-alat untuk proses kegiatan belajar mengajar.

Ada beberapa pendekatan yang digunakan oleh pihak humas di SMKN 1 Dlanggu untuk membangun komunikasi dengan masyarakat luas. Diantaranya memilih waktu yang tepat agar dapat berkumpul dan melibatkan masyarakat dalam kegiatan sekolah, kemudian memilih beberapa orang yang menjadi tokoh yang berpengaruh di masyarakat maupun instansi yang dapat diajak bekerja sama.

Dengan adanya prinsip dan pendekatan yang telah dilakukan pihak humas SMKN 1 Dlanggu, tentu sebuah lembaga pendidikan dapat dengan mudah menentukan jalan yang akan dihadapinya 
dalam menyelesaikan persoalan atau hambatan yang dihadapi dalam mengembangkan lembaganya sesuai dengan kebutuhan masyarakat, zaman dan kondisi yang ada di dalam maupun di luar lembaga pendidikan tersebut.

Dengan adanya humas dalam sebuah lembaga pendidikan sangat dibutuhkan dalam rangka mempertahankan eksistensi kelembagaan, karena sebagian besar masyarakat memandang semua lembaga pendidikan sebagai lembaga yang kompeten dalam bidang pendidikan bagi generasi penerus mereka. ${ }^{27}$

Untuk menjaga hal itu, menurut waka humas SMKN 1 Dlanggu menganggap masyarakat sebagai obyek utama dari program kerja humas dalam sebuah kelembagaan baik organisasi, perusahaan, maupun lembaga pendidikan. Mengingat kebutuhan dan kepentingan setiap orang yang semakin bermacammacam, maka pihak humas SMKN 1 Dlanggu dalam prosesnya betul-betul mengimplementasikan prinsip partisipasi masyarakat, sebab mereka menganggap masyarakat juga memegang dan menentukan kualitas dalam

\footnotetext{
27 Munirwan Umar, "Manajemen Hubungan Sekolah Dan Masyarakat Dalam Pendidikan," Edukasi 2, no. 1 (2016): 22.
}

mengembangkan lembaga pendidikannya. Dan dengan semakin tingginya tingkat partisipasi, semakin besar pula rasa memiliki dan tanggungjawab terhadap lembaga pendidikannya dan pada akhirnya semakin besar pula loyalitas yang dimiliki terhdap lembaganya.

Hal ini senada dengan penjelasan fauziyati, yang menerangkan perlunya menerapkan prinsip untuk meningkatkan keterlibatan masyarakat dalam bidang pendidikan. Sehingga mengharapkan lembaga pendidikan yang mampu berkomunikasi secara aktif dengan masyarakat. Adanya partisipasi publik internal maupun eksternal dalam mewujudkan lembaga pendidikan yang berkualitas perlu dimaksimalkan. ${ }^{28}$

Sedangkan ada beberapa strategi yang digunakan pihak humas di SMKN 1 Dlanggu yang aktif untuk menarik partisipasi masyarakat agar ikut andil dalam mengembangkan pendidikan yang dirasa cukup penting dalam menentukan keberhasilannya. Upaya-upaya humas dalam peningkatan partipasi masyarakat terhadap keberhasilan pengembangan pendidikan di sekolah, diantaranya:

$$
\text { 1. Menjalin hubungan }
$$

\footnotetext{
${ }^{28}$ Wiwin Rifatul Fauziyati, "Strategi Kepala Sekolah Untuk Meningkatkan Partisipasi Masyarakat Dalam Pendidikan Menuju Generasi Maju Indonesia," Qalamuna 10, no. 1 (2018): 167.
} 
komunikasi yang baik dengan

Orang Tua dan Masyarakat.

Orang tua dan masyarakat akan ikut berpartisipasi jika mereka juga merasakan manfaat dari keikutsertaannya dalam mengembangkan pendidikan di sekolah. Manfaat ini dapat diartikan sebagai kepedulian dan kepuasan karena dapat menyumbangkan kemampuan mereka bagi kepentingan sekolah. Dan ini menjadi hal penting dalam membina hubungan dengan orang tua dan masyarakat dalam menetapkan komunikasi yang efektif. $^{29}$

Di SMKN 1 Dlanggu mengupayakan partisipasi masyarakat melalui komunikasi langsung seperti temu wali murid di setiap program yang akan diberlakukan di sekolah. Dan biasanya ditindak lanjuti melalui grup sosial media.

2. Melakukan sosialisasi

Humas memang mempunyai tugas sebagai pemecah masalah dalam berkomunikasi pada masyarakat maupun institusi dan publik. Dan memang seharusnya humas secara intensif mensosialisasikan lembaganya secara terbuka dan menyeluruh. ${ }^{30}$

Sama halnya dengan pihak humas yang berada di SMKN 1 Dlanggu, juga melakukan sosialisasi dengan berbagai macam cara dan pendekatan. Diantaranya seperti mengirim surat ke banyak SMP setiap tahunnya yang berisi tentang profil sekolah, ditindak lanjuti dengan mendatangi SMP dan biasanya ada sekitar 15 SMP per tahun yang harus diberi sosialisasi, mengikut sertakan peserta didik di setiap perlombaan baik lokal maupun nasional, serta banyak lagi cara dan pendekatan yang digunakan untuk tujuan sosialisasi.

3. Kerja sama dengan instansi lain

Seperti halnya di SMKN 1 Dlanggu juga menerapkan kerjasama yang menjadi program sekolah yang disebut prakerin (praktek kerja industri). Hal ini didukung dengan sebagian besar jurusan yang beberapa kompetensinya hanya bisa didapat secara

${ }^{29}$ Ibid., 173.

${ }^{30}$ Zubair, Dewi, and Kadarisman, "Strategi Komunikasi Publik Dalam Membangun Pemahaman Mahasiswa Terhadap Penerapan Ptnbh," 76. 
langsung di lapangan.

Diantaranya bekerja sama dengan pihak perhotelan yang memiliki standar tinggi untuk jurusan APH (akomodasi perhotelan) dan tata boga, untuk jurusan animasi bekerja sama dengan studio animasi yang biasa bertempat di kota Malang, sedangkan jurusan multimedia bekerja sama dengan stasiun TV dan percetakan, dan masih banyak jurusan yang ada di SMKN 1 Dlanggu dan industri-industri yang diajak bekerja sama.

Dalam lingkup sekolah kejuruan, kerjasama dengan instansi lain menjadi kewajiban. Karena pembelajaran di lingkup sekolah kejuruan tidak dapat hanya dikerjakan di dalam kelas saja, namun juga harus dilaksanakan pemebelajaran yang bersifat langsung di industri tau tempat kerja. Dengan adanya kerjasam yang baik dan kuat, dapat menyiapkan lulusan yang kompeten dalam bidangnya dan memiliki daya saing yang tinggi. $^{31}$

Sekolah sebagai lembaga/organisasi yang mewujudkan sumber daya manusia tingkat tinggi harus mampu mengarahkan seluruh peserta didiknya agar dapat memiliki kompetensi yang tinggi dibidangnya agar minimal mereka dapat mempunyai pandangan visioner sebagai motor penggerak dalam kehidupannya terlebih lagi untuk memajukan bangsa dan Negaranya.

$$
\text { Sedangkan }
$$

masyarakat

menentukan tujuan, strategi dan perwakilannya dalam pelaksanaan kebijakan sebagai keterlibatan masyarakat dalam keseluruhan proses dan pengembangan masyarakat sesuai dengan arti pembangunan sendiri. Oleh karena itu program humas harus dilaksanakan secara harmonis, artinya lembaga dan masyarakat harus saling bekerja sama, bahu membahu, tolong menolong untuk mewujudkan visi, misi dan tujuan sekolah secara efektif dan efisien.

Untuk memperbaiki kinerja humas selama melaksanakan semua program-program humas, tentu diperlukan evaluasi untuk mengamati,

${ }^{31}$ Ahmad Dardiri, "Optimalisasi Kerjasama Praktik Kerja Industri Untuk Meningkatkan Citra Sekolah Dan Daya Saing Lulusan SMK," Jurnal Pendidikan dan Pembelajaran 22, no. 2 (2015): 163164. 
mengoreksi dan menilai selama proses manajerial maupun pelaksanaan programprogram humas. Sehingga dapat diketahui dengan jelas, program mana yang sudah terlaksana dengan baik atau kurang maksimal. Dan evaluasi ini difokuskan kepada evaluasi proses selama program berlangsung dan hasil ketika program telah terlaksana. ${ }^{32}$ Dengan begitu, evaluasi dapat digunakan untuk mempermudah dan sebagai tolak ukur dalam menentukan perbaikan program dan menentukan program-program lanjutan yang lebih efektif dan efisien dari pada program sebelumnya.

Pihak humas dari SMKN 1 Dlanggu selalu melakukan evaluasi diri untuk berbagai macam program yang telah dilakukan, karena merasa perlu untuk melakukan evaluasi. Evaluasi untuk humas di SMKN 1 Dlanggu biasanya dilakukan oleh pihak humas ketika suatu program telah dilaksanakan dengan menyeluruh. Dan evaluasi juga dilakukan ketika berada di akhir ajaran oleh pihak manajemen sekolah.

Model evaluasi ini dilakukan untuk memudahkan pihak humas mengetahui kinerja selama program dilaksanakan sampai selesai, sedangkan evaluasi akhir tahun ajaran dilakukan untuk memantapkan hasil evaluasi dari pihak humas oleh pihak manajemen sekolah. Karena humas hanya terdiri dari

\footnotetext{
${ }^{32}$ Muhammad Nur Hakim and Fitriani Dwi Rahayu, "Pembelajaran Saintifik Berbasis Pengembangan Karakter," Nazhruna: Jurnal Pendidikan Islam 2, no. 1 (2019): 22.
}

beberapa orang saja, dan apabila evaluasi dilakukan oleh lebih banyak orang tentu akan mudah mendapatkan kritik, saran, dan pendapat yang membangun untuk pengembangan humas selanjutnya. Yang nantinya hasil evaluasi dari seluruh pihak sekolah mempermudah pihak humas SMKN 1 Dlanggu mengamati dan menilai seluruh program yang telah dilaksanakan dan menentukan serta memodifikasi program-program yang akan dilaksanakan di tahun ajaran berikutnya.

Seperti halnya yang dikemukakan oleh harini dan karwanto bahwa dalam sebuah evaluasi atau sebuah penilaian digunakan agar dapat mengkaji pelaksanaan suatu program yang telah direncanakan yang mana terdiri atas program-program yang dalam penyusunannya ditunjang oleh hasil penyelidikan dan penilaian yang dilakukan secara cermat, dan dalam evaluasi tentu dilakukan penyelidikan dan penilaian terhadap hambatan yang ada dalam proses maupun hasil dari suatu program. $^{33}$

Dengan model evaluasi yang dilaksanakan oleh humas SMKN 1 Dlanggu yang seperti itu, tentu akan mendukung dan mewujudkan pendidikan di SMKN 1 Dlanggu lebih berkembang dan berkualitas. Karena upaya perbaikan dan pengembangan yang dilakukan secara

33 Harini and Karwanto, "Manajemen Hubungan Masyarakat Dalam Upaya Peningkatan Pencitraan Sekolah,” 16-17. 
menyeluruh dari semua komponenkomponen yang ada telah dilaksanakan dengan teratur dan sungguh-sungguh.

\section{KESIMPULAN}

Pada dasarnya, manajemen humas (hubungan masyarakat) merupakan bidang atau fungsi tertentu yang diperlukan oleh setiap lembaga terutama lembaga pendidikan, baik itu lembaga yang bersifat komersial (perusahaan) maupun lembaga yang non komersial. Namun humas sendiri mempunyai pengertian keseluruhan upaya yang dilangsungkan secara terencana dan berkesinambungan dalam rangka menciptakan dan memelihara niat baik dan saling pengertian antara suatu lembaga dengan segenap publiknya. Jadi, humas adalah suatu rangkaian kegiatan yang diorganisasi sedemikian rupa sebagai suatu rangkaian kampanye atau program terpadu, dan semuanya itu berlangsung secara berkesinambungan dan teratur.

Sekolah sebagai lembaga pendidikan dituntut untuk dapat mewujudkan sumber daya manusia tingkat tinggi yang harus mampu mengarahkan seluruh peserta didiknya agar dapat memiliki kompetensi dibidangnya agar mereka dapat mempunyai pandangan visioner sebagai motor penggerak dalam kehidupannya. Sedangkan masyarakat dalam keterlibatannya di dunia pendidikan menentukan tujuan, strategi dan perwakilannya dalam pelaksanaan kebijakan sebagai bentuk kepedulian masyarakat dalam keseluruhan proses dan pengembangan masyarakat sesuai dengan arti pembangunan suatu bangsa itu sendiri. Oleh karena itu program humas harus dilaksanakan secara harmonis.

Evaluasi diri untuk humas dapat dilakukan dengan berbagai macam cara, dan yang terpenting dapat mengamati dan menilai program yang telah dilakukan dengan seksama. Seperti evaluasi yang dilakukan dengan cara fokus pada proses dan hasil dari suatu program yang telah dilaksanakan oleh humas. Yang mana pihak humas dapat mengevaluasi suatu program setelah program itu terlaksanakan dengan menyeluruh. Dan sekaligus evaluasi juga dilakukan ketika berada di akhir tahun ajaran oleh pihak manajemen sekolah, agar lebih memantapkan evaluasi dari pihak humas sendiri. 


\section{Daftar Pustaka}

Anwar, Rofiq. "Peran Praktisi Public Relations Dalam OrganisasiOrganisasi Di Yogyakarta." An-Nida 7, no. 1 (2015): 46-55.

Dardiri, Ahmad. “Optimalisasi Kerjasama Praktik Kerja Industri Untuk Meningkatkan Citra Sekolah Dan Daya Saing Lulusan SMK." Jurnal Pendidikan dan Pembelajaran 22, no. 2 (2015): 162-168.

Fauziyati, Wiwin Rifatul. "Strategi Kepala Sekolah Untuk Meningkatkan Partisipasi Masyarakat Dalam Pendidikan Menuju Generasi Maju Indonesia." Qalamuna 10, no. 1 (2018): 157-177.

Hakim, Muhammad Nur. "Implementasi Manajemen Berbasis Sekolah Dalam Mewujudkan Sekolah Islam Unggulan." Nidhomul Haq: Jurnal Manajemen Pendidikan Islam 1, no. 2 (2016): 104-114. Accessed November 3, 2018. http://ejournal.ikhac.ac.id/index.php/nidho mulhaq/article/view/7.

Hakim, Muhammad Nur, and Fitriani Dwi Rahayu. "Pembelajaran Saintifik Berbasis Pengembangan Karakter." Nazhruna: Jurnal Pendidikan Islam 2, no. 1 (2019): 1-27.
"Manajemen Hubungan Masyarakat Dalam Upaya Peningkatan Pencitraan Sekolah." Jurnal Inspirasi Manajemen Pendidikan 4, no. 4 (2014): 8-20.

Hasbana, Amrullah. "Perpustakaan Sebagai Lembaga Komunikasi Organisasi Kampus." Al-Maktabah 13, no. 1 (2014): 50-57.

Irawan, Enjang Pera. "Penerapan Peran Public Relations Pada Program Employee Relations Sebagai Upaya Meningkatkan Loyalitas Karyawan.” LONTAR: Jurnal Ilmu Komunikasi, no. 2 (2018): 15-26. Accessed February 25, 2019. http://ejurnal.lppmunsera.org/index.php/L ONTAR/article/view/538.

Mas, Sitti Roskina. "Partipasi Masyarakat Dan Orang Tua Dalam Penyelengaraan Pendidikan." Jurnal el-Hikmah VIII, no. 2 (2011): 184 196. http://ejournal.uinmalang.ac.id/index.php/elhikmah/a rticle/view/2243/pdf.

Mundiri, Akmal. "Strategi Lembaga Pendidikan Islam Dalam Membangun Branding Image." Pedagogik 3, no. 2 (2016): 58-72.

Munirwan Umar. "Manajemen Hubungan Sekolah Dan Masyarakat Dalam Pendidikan." Edukasi 2, no. 1 (2016): 18-29. 
Di Lembaga Pendidikan: Konsep,

Fenomena, Dan Aplikasinya. Malang: UMM Press, 2010.

Samsuni, Samsuni. "Manajemen Sumber Daya Manusia." Al-Falah: Jurnal Ilmiah Keislaman dan Kemasyarakatan 17, no. 1 (March 1, 2017): 113-124. Accessed February 20, 2019. http://ejurnal.staialfalahbjb.ac.id/in dex.php/alfalahjikk/article/view/19

Syarifudin, E. Manajemen Pendidikan. Jakarta: Diadit Media, 2011.

Winarni, F. "Reorientasi Pendidikan Nilai Dalam Menyiapkan Kepemimpinan Masa Depan." Cakrawala Pendidikan XXV, no. 1 (2006): 139-171.

Yaqien, Nurul. "Membangun Kepercayaan Masyarakat Pada Madrasah Melalui Pameran Pendidikan." Madrasab 2, no. 2 (2010): 192-206.

Yogi Irfan Rosyadi, Pardjono. "Peran Kepala Sekolah Sebagai Manajer Dalam Meningkatkan Mutu Pendidikan Di SMP 1 Cilawu Garut." Jurnal Akuntabilitas Manajemen Pendidikan 3, no. 1 (2015): 124-133.

Zubair, Feliza, Retasari Dewi, and Ade
Kadarisman. "Strategi Komunikasi

Publik Dalam Membangun

Pemahaman Mahasiswa Terhadap Penerapan Ptnbh." Profetik Jurnal

Komunikasi 11, no. 2 (2018): 74-84. 